\title{
Anti-Insulin Receptor Antibodies Inhibit Insulin Binding and Stimulate Glucose Metabolism in Skeletal Muscle
}

\author{
Y. Le Marchand-Brustel, P. Gorden, J. S. Flier, C. R. Kahn, and P. Freychet \\ Institut National de la Santé et de la Recherche Médicale U. 145, Nice, France, and Diabetes Branch, National Institute of Arthritis, \\ Metabolism and Digestive Diseases, National Institutes of Health, Bethesda, Maryland, USA
}

Summary. Autoantibodies against the insulin receptor are found in the serum of some patients with severe insulin resistance. The effects of one of these sera on insulin binding and on glucose transport and metabolism were investigated in the isolated mouse soleus muscle. Preincubation of muscles with the patient's serum resulted in an inhibition of subsequent ${ }^{125} \mathrm{I}$-insulin binding (half-maximal effect at $1: 500$ dilution) and in a two to three-fold stimulation of glucose transport and metabolism (half-maximal effect at 1:2000 dilution). The insulin-like effects were blocked by anti-human $\operatorname{IgG}$, but not by antiinsulin antibodies. The magnitude of the serum effects on 2-deoxyglucose uptake and glycolysis was similar to that of insulin, but the effect on glycogen synthesis was smaller than that of insulin. It is suggested that the patient's serum and insulin promote glucose transport and glycolysis through a common pathway, but act differently on glycogen synthesis.

Key words: Anti-insulin receptor antibodies, insulinlike effects, insulin resistance, skeletal muscle, insulin receptor, insulin binding, insulin action, glucose transport, glycolysis, glycogen synthesis, obese mice.

A group of patients has recently been described $[1,2]$ who are characterized by severe insulin resistance, acanthosis nigricans and a markedly altered insulin binding to its receptor $[3,4]$. Some of these patients, referred to as type B [2], have a circulating antibody which has been shown to specifically inhibit insulin binding to a variety of cells (monocytes, rodent liver membranes, adipocytes) $[1,5,6,7]$. These immunoglobulins also exert stimulatory effects on glucose oxidation and metabolism in isolated rat adipocytes
$[6,7]$. In the present study, we have investigated the effects of the most potent of these sera (patient B-2, ref 2) in the isolated mouse soleus muscle. We have previously shown $[8,9]$ that the isolated soleus muscle is a suitable system to measure specific insulin binding and insulin effects on glucose metabolism.

\section{Materials and Methods}

\section{Animals}

Eight week-old male Swiss albino mice were fed ad libitum with UAR laboratory chow (Villemoisson, Epinay/Orge, France), containing $21 \%$ protein, $4 \%$ fat and $51 \%$ carbohydrate, until the time of sacrifice (9-11 a. m.). They were maintained in a constanttemperature $\left(23^{\circ} \mathrm{C}\right)$ animal room, with a fixed $12 \mathrm{~h}$ artificial light cycle. Ten week-old male obese $(\mathrm{C} 57 \mathrm{BL} / 6 \mathrm{~J}, o b / o b)$ mice and their lean controls $(\mathrm{C} 57 \mathrm{BL} / 6 \mathrm{~J},+/+)$ were purchased from the Jackson Laboratory, Bar Harbor.

\section{Soleus Muscle Isolation and Incubation}

Mice were killed by cervical dislocation and soleus muscles were isolated as previously described $[9,10]$. Each individual muscle was isolated free from the leg, attached to a stainless steel holder and placed in a flat bottomed glass tube. They were immersed in $1.5 \mathrm{ml}$ of Krebs-Ringer bicarbonate buffer ( $\mathrm{pH} 7.4$ ) [11] containing $20 \mathrm{mg} / \mathrm{ml}$ defatted bovine albumin and pyruvate $(2 \mathrm{mmol} / \mathrm{l})$. The tubes were sealed with rubber stoppers and gassed with $\mathrm{O}_{2}: \mathrm{CO}_{2}(95: 5$, vol :vol) during the first $10 \mathrm{~min}$ of the preincubation or incubation periods. Muscles were always preincubated at $37^{\circ} \mathrm{C}$ for a first $15 \mathrm{~min}$ period without serum and then transferred to another vial for a second 90 
min preincubation. Serum from a control (normal, overnight fasted) subject or from patient B-2. (see ref. 2 for the description of this patient) was present only during this $90 \mathrm{~min}$ preincubation period. At the end of this period, muscles were washed twice for 5 min at $20^{\circ} \mathrm{C}$, in $1.25 \mathrm{ml}$ of Krebs-Ringer bicarbonate buffer $(\mathrm{pH} 7.4)$ containing $5 \mathrm{mg} / \mathrm{ml}$ defatted bovine albumin. Therefore, all studies were performed by preincubating muscles with serum and then washing to remove all serum factors not tightly bound to the muscle (serum specimens diluted over 100 -fold had no detectable insulin by radioimmunoassay [3]). Muscles were then incubated, without serum, using the following procedure.

\section{Insulin Binding Studies}

Muscles were incubated in $1.5 \mathrm{ml}$ of the same medium as that described above for the first $(15 \mathrm{~min})$ preincubation, containing ${ }^{125} \mathrm{I}$-insulin $(1 \mathrm{ng} / \mathrm{ml}, 0.17$ nmol/1; specific activity, about $200 \mu \mathrm{Ci} / \mu \mathrm{g}$ ) without or with varying concentrations of unlabelled insulin, as indicated in the figures. The incubation was continued for $3 \mathrm{~h}$ at $20^{\circ} \mathrm{C}$. Some muscles were incubated in the presence of unlabelled insulin $(6 \mu \mathrm{mol} / \mathrm{l})$ to measure non-specific binding, which has been subtracted from all binding data. At the end of the $3 \mathrm{~h}$ period, which achieved a steady state of insulin binding [9], muscles were washed six times with $5 \mathrm{ml}$ of chilled $\mathrm{NaCl}(0.154 \mathrm{~mol} / \mathrm{l})$ containing $2.5 \mathrm{mg} / \mathrm{ml}$ of human serum albumin, each washing step consisting of a $5 \mathrm{~min}$ incubation period. After washing, muscles were dissolved in $0.3 \mathrm{ml}$ of $\mathrm{NaOH}(1 \mathrm{~mol} / \mathrm{l})$ and counted for ${ }^{125}$ I-radioactivity. An aliquot sample of the solution was kept for protein determination of each individual muscle preparation, human serum albumin being used as standard [12].

\section{Deoxyglucose Uptake Studies}

Muscles were incubated for $15 \mathrm{~min}$ at $20^{\circ} \mathrm{C}$ in $1.5 \mathrm{ml}$ of the same medium containing $1{ }^{14} \mathrm{C}$-2-deoxyglucose $(0.5 \mathrm{mmol} / 1,0.5 \mu \mathrm{Ci} / 1.5 \mathrm{ml})$. Initial rates of uptake are measured under these conditons of temperature and incubation duration [9]. Muscles were then washed and dissolved in $\mathrm{NaOH}$ as described above. An aliquot sample of the solution was counted in a liquid scintillation counter for determination of ${ }^{i t} \mathrm{C}$ radioactivity.

\section{Glucose Metabolism Studies}

Glucose utilization by muscle was studied by measuring the rate of formation of ${ }^{3} \mathrm{H}_{2} \mathrm{O}$ from $5-{ }^{3} \mathrm{H}$-D-glucose, an index of glycolysis [13], and the incorpora- tion of ${ }^{3} \mathrm{H}$ into glycogen. Muscles were incubated for $60 \mathrm{~min}$ at $37^{\circ} \mathrm{C}$ in $1.5 \mathrm{ml}$ Krebs-Ringer bicarbonate buffer ( $\mathrm{pH} 7.4$ ) containing $20 \mathrm{mg} / \mathrm{ml}$ defatted bovine albumin and $5-{ }^{3} \mathrm{H}$-D-glucose $(2 \mathrm{mmol} / 1, \quad 1 \mu \mathrm{Ci} /$ $1.5 \mathrm{ml}$ ). At the end of incubation, ${ }^{3} \mathrm{H}_{2} \mathrm{O}$ in the medium and labelled glycogen in muscles were measured as described elsewhere [10]. When the effect of insulin $(200 \mathrm{ng} / \mathrm{ml})$ was compared to the effect of serum, insulin was present only during the incubation period.

All results are presented as the mean \pm SEM of 4-8 different muscles as indicated in the legends to figures. Statistical significance was assessed by Student's $t$ test for unpaired comparisons [14].

\section{Materials}

${ }^{125}$ I-insulin was iodinated and purified as described previously [9]. Porcine monocomponent insulin was a gift of J. Schlichtkrull (Novo Research Institute, Copenhagen, Denmark) and G. Jouve (Novo Paris, France). Radioactive substances were purchased from the Radiochemical Centre (Amersham, England). Defatted bovine serum albumin was from Sigma (Saint-Louis, Mo). Other chemicals were purchased from Merck AG (Darmstadt, West Germany) or from Fluka AG (Buchs, Switzerland).

\section{Results}

\section{Effect of Serum B-2 on Insulin Binding to Soleus} Muscle

When muscles were exposed to serum B-2 during the preincubation, there was a subsequent decrease of ${ }^{125}$ I-insulin binding (Fig. 1). Preincubation with control serum used at the lowest dilution $(1: 30)$ did not significantly modify ${ }^{125}$ I-insulin binding when compared to muscles preincubated without serum (buffer). With $1: 30$ dilution of serum B-2, insulin binding was decreased by $70 \%$, which is analogous to the inhibitory effect of unlabelled insulin observed in this system with $200 \mathrm{ng} / \mathrm{ml}(33 \mathrm{nmol} / \mathrm{l})$ (Fig. 2). Fifty percent inhibition of ${ }^{125}$ I-insulin binding was observed with serum B-2 at $1: 200$ dilution (Fig. 1).

To determine the nature of the inhibitory effect, the concentration dependence of ${ }^{125} \mathrm{I}$-insulin binding was studied in muscles preincubated with $1: 200$ dilution of control serum or of serum B-2 (Fig. 2). Because this binding system, which uses individual muscles, is not conveniently suited for a large number of concentration points, Scatchard analysis of the data was not performed. However, the inhibition of binding was greater at low concentrations of insulin and decreased with increasing insulin concentration, 


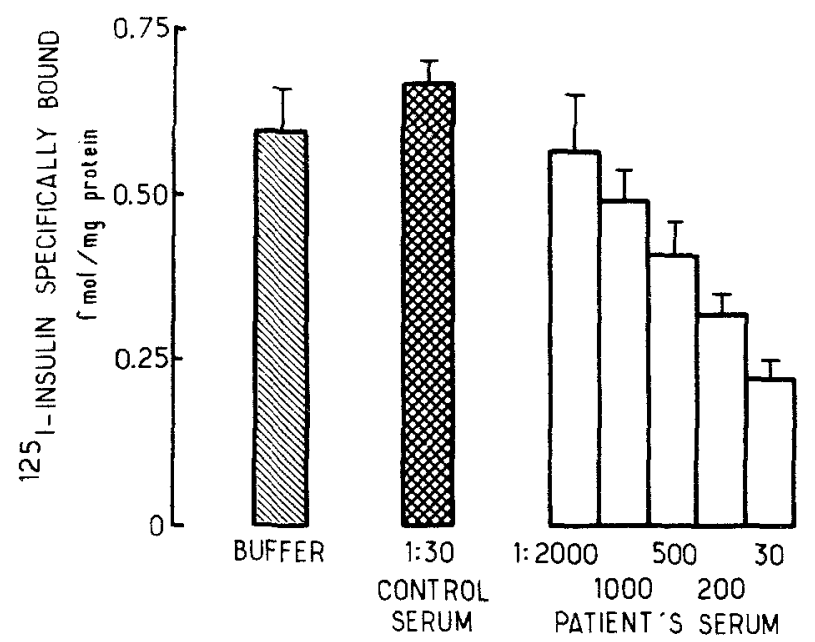

Fig. 1. Effect of serum B-2 on ${ }^{125}$-I-insulin binding to soleus muscle. Muscles were preincubated in the absence (buffer) or in the presence of various dilutions of serum before measuring insulin binding as described in Methods. The non-specific binding, measured in the presence of unlabelled insulin $(6 \mu \mathrm{mol} / \mathrm{l})$, represented $21 \%$ of the total binding and has been subtracted from each point. Each point is the mean \pm SEM of 4-5 muscles

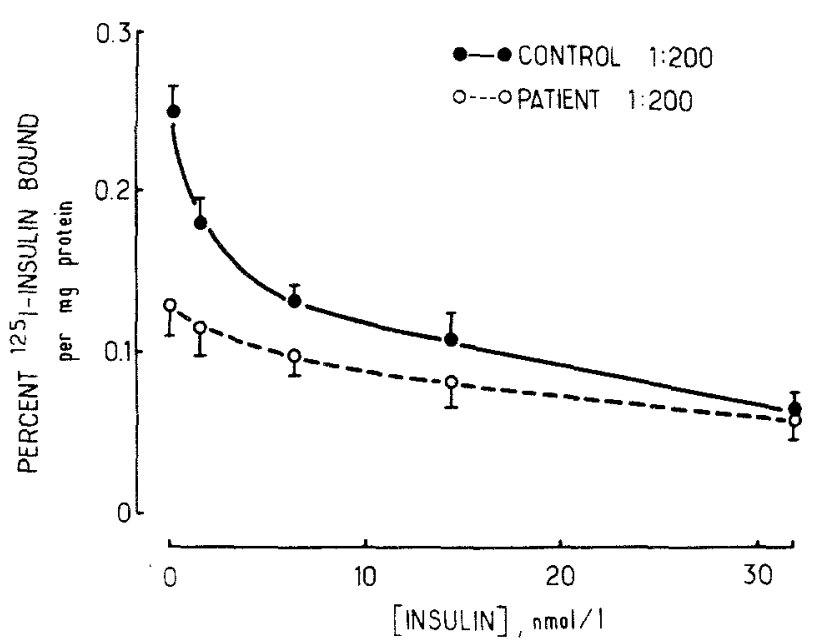

Fig. 2. Effect of serum B-2 on the inhibition curve of ${ }^{125}$ I-insulin binding by insulin. Muscles were preincubated with a $1: 200$ dilution of serum before measuring insulin binding as described in Methods. The non-specific binding was measured as described in Figure 1 and has been subtracted from each point. Each point is the mean \pm SEM of 8 muscles. Differences between control and patient's serum are statistically significant with $P<0.01$ for the 2 lowest concentrations of insulin. Differences are not significant for the 3 highest concentrations

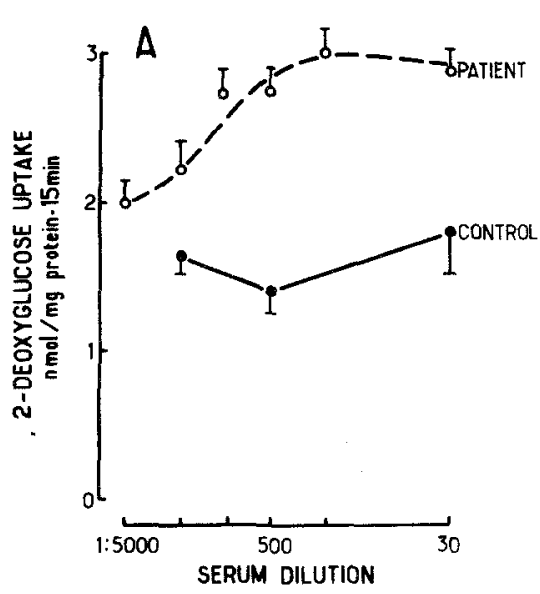

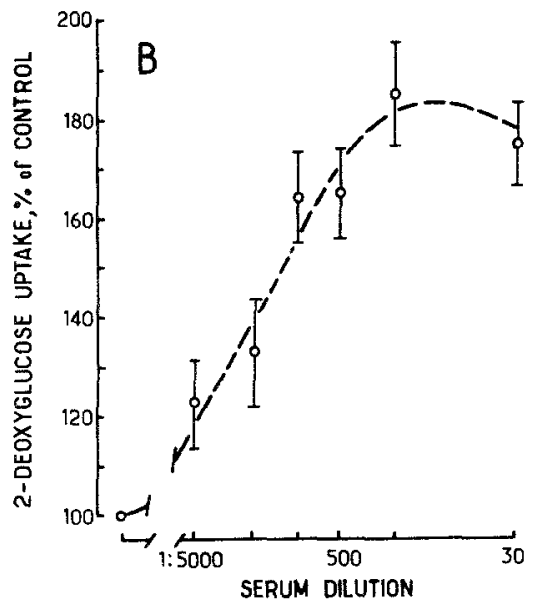

Fig. 3. Effect of serum B-2 on 2-deoxyglucose uptake in soleus muscle. Muscles were preincubated with serum before measuring 2-deoxyglucose uptake as described in Methods. Deoxyglucose uptake is expressed as nmoles per $\mathrm{mg}$ protein and per $15 \mathrm{~min}$ (A) or as percent of control values (B). Each point is the mean \pm SEM of $4-5$ muscles. Differences between control and patient are statistically significant with $P<0.01$ for all dilutions of serum except $1: 5000$ (control value was taken as the average of the results observed with three dilutions of control serum, since all three values did not differ significantly from each other) suggesting that the decrease in ${ }^{125} \mathrm{I}$-insulin binding could be accounted for mainly by a decrease in receptor affinity rather than by a change in receptor number. This is also suggested by the observation that about twice as much insulin was required to obtain $50 \%$ of maximal inhibition of ${ }^{125}$ I-insulin binding in muscles pretreated with serum B-2 compared to control muscles.

\section{Effect of Serum B-2 on 2-Deoxyglucose Uptake and Glucose Metabolism}

Preincubation of muscles with serum B-2 increased the basal rate of 2-deoxyglucose uptake (Fig. 3), gly- colysis and glycogen synthesis (Fig. 4). A statistically significant stimulatory effect of serum B-2 could be observed with a dilution as great as $1: 2000$; maximal effect was reached with $1: 200$ dilution (Fig. 3 and 4). Preincubation of muscles with control serum did not modify 2-deoxyglucose uptake (Fig. 3, Table 1) or glucose metabolism (Fig. 4). The same stimulatory effect of serum B-2 persisted when muscles, following preincubation with serum, were incubated for 3 additional hours at $20^{\circ} \mathrm{C}$ in serum-free medium before measuring 2-deoxyglucose uptake (Table 1). The maximal effect of serum B-2 on 2-deoxyglucose uptake was comparable to the effect produced by a maximally-stimulating dose of insulin in the same 

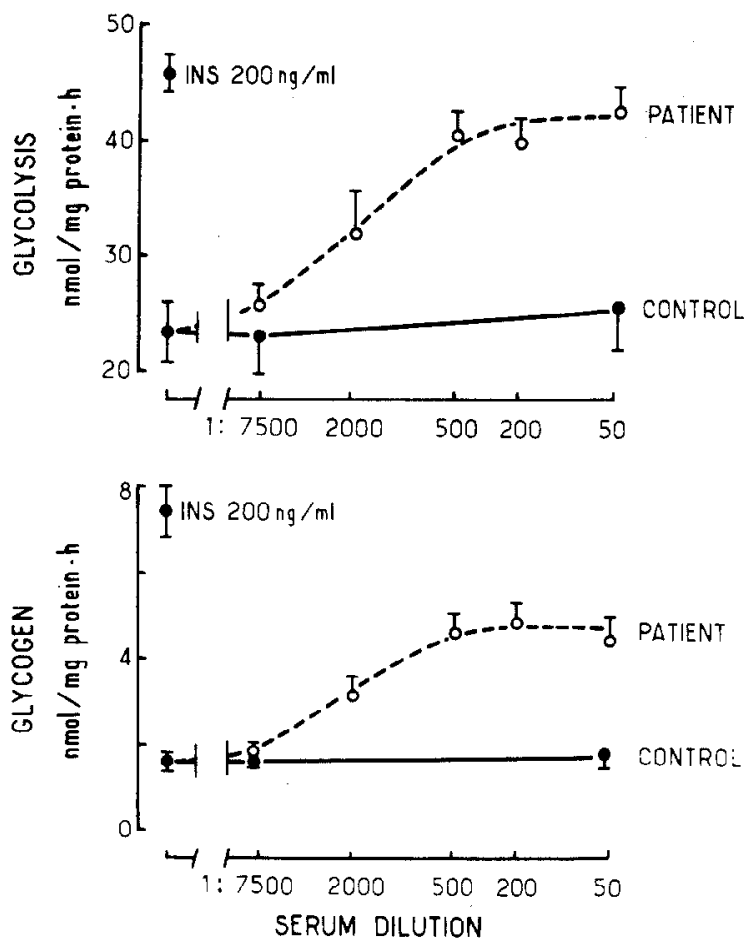

Fig. 4. Effect of serum B-2 on glucose metabolism in soleus muscle. Muscles were preincubated with serum before measuring glucose metabolism as described in Methods. Some muscles were preincubated without serum and incubated in the absence or in the presence of insulin $(200 \mathrm{ng} / \mathrm{ml})$. Each point is the mean $\pm S E M$ of 4-5 muscles. The stimulatory effect of patient's serum was statistically significant at all dilutions tested with at least $P<0.05$, except for the $1 / 7500$ dilution. For glycogen synthesis, the difference between the effects of insulin and patient's serum is significant with $\mathrm{P}<0.02$

incubation conditions (2-deoxyglucose uptake was $200 \%$ of control with $200 \mathrm{ng} / \mathrm{ml}$ insulin, not shown on figure). The increase in 2-deoxyglucose uptake after preincubation with serum B-2 was paralleled by an increase in glycolysis and glycogen synthesis (Fig. 4). However, whereas a maximally-stimulating concentration of insulin $(200 \mathrm{ng} / \mathrm{ml})$ and preincubation with serum B-2 at $1: 200$ to $1: 50$ dilution stimulated glycolysis to a similar extent, serum B-2 was less effective than insulin in stimulating glycogen synthesis (Fig. 4); thus, serum B-2 caused a 190\% increase and insulin caused a $350 \%$ increase in glycogen synthesis over basal.

\section{Specificity of Effect of Serum B-2 on Glucose Metabolism in Soleus Muscle}

The stimulatory effect of serum B-2 on glucose metabolism was virtually abolished when the serum was preincubated with an antihuman IgG serum (Table 2). In contrast, preincubating serum B-2 with anti-insulin serum (neutralizing capacity $2.16 \mathrm{U} / \mathrm{ml}$ )

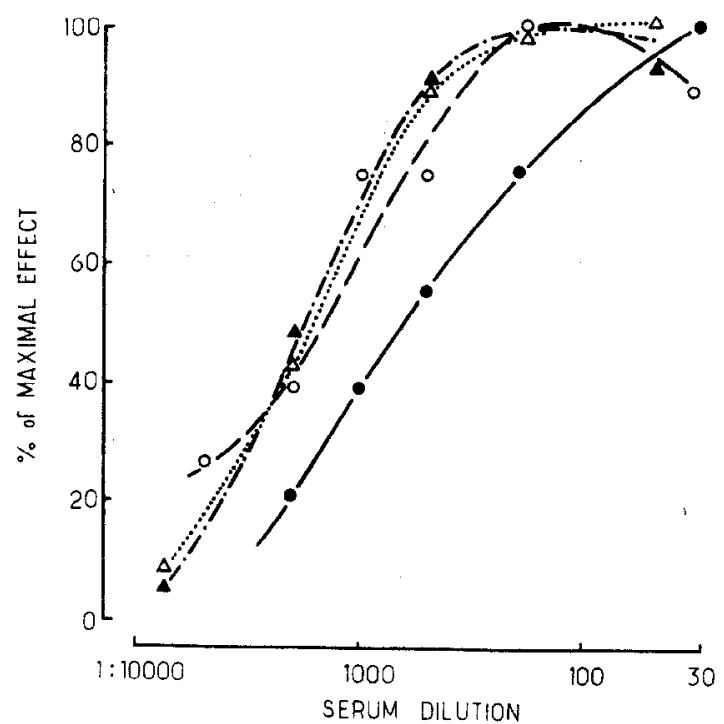

Fig. 5. Comparison of effects of serum B-2 on ${ }^{125}$ I-insulin binding, 2-deoxyglucose uptake, and glucose metabolism in soleus muscle. Muscles were preincubated and incubated as described in Methods. The effect of serum B-2 on insulin binding (-_ ) is expressed as the percentage of the maximal inhibition achieved with a $1: 30$ dilution of the serum. Deoxyglucose uptake $\left(\mathrm{O}_{-} \mathrm{O}^{-}\right.$), glycolysis $(\triangle \ldots \triangle)$ and glycogen synthesis $(\boldsymbol{\Delta}-.-\mathbf{\Delta})$, are expressed as the percentage of maximal stimulation. These values were determined by dividing for each type of effect the increment due to serum B-2 at each dilution (stimulated value-control value) by the maximal increment produced by a $1: 200$ dilution of the serum

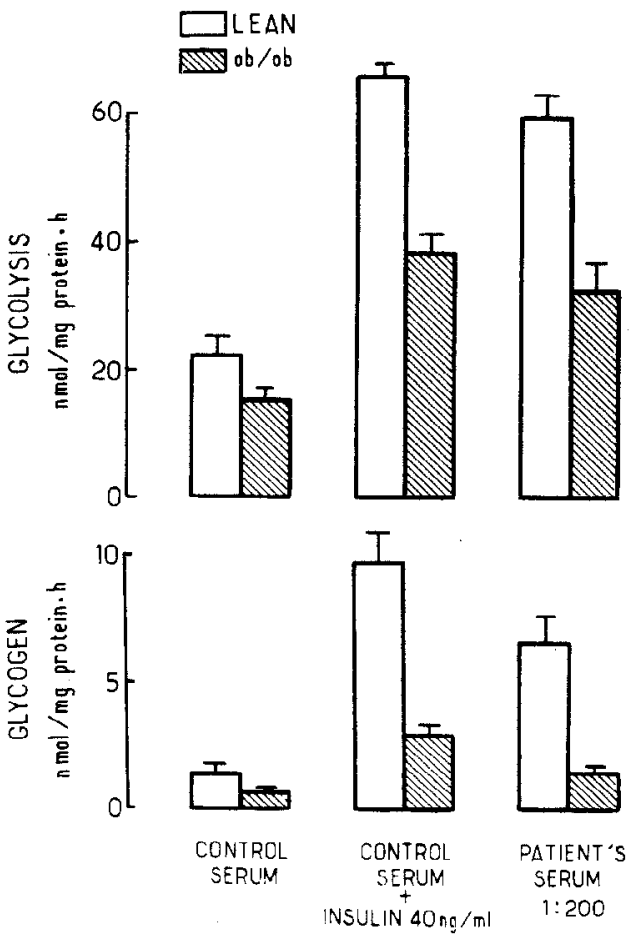

Fig. 6. Effect of insulin and serum B-2 in soleus muscle of lean and $a b / a b$ mice. Muscles were preincubated with a 1:200 dilution of serum before measuring glucose metabolism as described in Methods. Insulin, when indicated, was present during the $60 \mathrm{~min}$ incubation period. The results are expressed as described in Fig. 4 and represent means \pm SEM of 5 muscles 
Table 1. Persistence of effect of serum B-2 on 2-deoxyglucose uptake in soleus muscle

\begin{tabular}{ll}
\hline $\begin{array}{l}\text { Preincubation } \\
\text { conditions }\end{array}$ & $\begin{array}{l}\text { 2-deoxyglucose uptake } \\
\text { nmol/mg protein. } 15 \mathrm{~min} .\end{array}$ \\
\hline $\begin{array}{l}\text { No serum } \\
\text { Control serum }\end{array}$ & $1.13 \pm 0.06$ \\
$1: 500$ & $1.06 \pm 0.07$ \\
$1: 200$ & $1.00 \pm 0.11$ \\
$1: 30$ & $1.02 \pm 0.06$ \\
Serum B-2 & \\
$1: 2000$ & $1.24 \pm 0.12$ \\
$1: 1000$ & $1.41 \pm 0.15$ \\
$1: 500$ & $1.43 \pm 0.09$ \\
$1: 200$ & $1.74 \pm 0.13$ \\
$1: 30$ & $1.53 \pm 0.09$ \\
\hline
\end{tabular}

Muscles were preincubated as indicated in Figure 3. After 2 washes, muscles were incubated for $3 \mathrm{~h}$ at $20^{\circ} \mathrm{C}$ in medium without serum before the addition of $1-{ }^{14} \mathrm{C}$-deoxyglucose (final concentration $0.5 \mathrm{mmol} / 1,0.5 \mu \mathrm{Ci} / 1.5 \mathrm{ml}$ ) for $15 \mathrm{~min}$. Each value is the mean \pm SEM of 4 muscles

Table 3. Combined effects of serum B-2 and insulin on glucose metabolism in soleus muscle

\begin{tabular}{|c|c|c|c|}
\hline & \multicolumn{3}{|c|}{ Preincubation with } \\
\hline & $\begin{array}{l}\text { Control } \\
\text { serum } \\
1: 200\end{array}$ & $\begin{array}{l}\text { Serum } \\
\text { B-2 } \\
1: 3000\end{array}$ & $\begin{array}{l}\text { Serum } \\
\text { B-2 } \\
1: 200\end{array}$ \\
\hline \multicolumn{4}{|c|}{$\begin{array}{l}\text { Glycolysis } \\
\text { Insulin (ng/ml) }\end{array}$} \\
\hline $\begin{array}{r}0 \\
4 \\
200\end{array}$ & $\begin{array}{l}30.1 \pm 1.9 \\
45.5 \pm 2.3 \\
56.9 \pm 4.4\end{array}$ & $\begin{array}{l}43.7 \pm 2.1 \\
50.5 \pm 1.6\end{array}$ & $\begin{array}{l}55.9 \pm 2.4 \\
51.6 \pm 1.5\end{array}$ \\
\hline \multicolumn{4}{|c|}{ Glycogen synthesis } \\
\hline $\begin{array}{r}0 \\
4 \\
200\end{array}$ & $\begin{array}{l}1.7 \pm 0.3 \\
3.9 \pm 0.4 \\
5.9 \pm 0.2\end{array}$ & $\begin{array}{l}2.6 \pm 0.5 \\
4.6 \pm 0.7\end{array}$ & $4.4 \pm 0.3$ \\
\hline
\end{tabular}

Muscles were preincubated with the indicated concentrations of control serum or serum B-2 as described in Figure 4. Insulin was added during the incubation period. Glycolysis and glycogen synthesis were measured at the end of a 60 min incubation with 5${ }^{3} \mathrm{H}$-D-glucose $(2 \mathrm{mmol} / \mathrm{l})$ as described in Methods. The results, expressed as nanomoles of glucose converted into $\mathrm{H}_{2} \mathrm{O}$ (through the glycolytic pathway) or incorporated into glycogen per $\mathrm{mg}$ of protein, are the means \pm SEM of 5 to 6 muscles did not significantly affect the stimulation of glucose metabolism (Table 2). As shown in Table 3, the stimulatory effects of serum B-2 and insulin used both at submaximal concentrations (respectively, $1: 3000$ dilution and $4 \mathrm{ng} / \mathrm{ml}$ ) were partly additive for glycolysis and glycogen synthesis, whereas no additive effects were observed when both were used at maximally effective concentrations (1:200 dilution and $200 \mathrm{ng} / \mathrm{ml}$ ).

\section{Relationship between the Effects of Serum B-2 on Insulin Binding and on Glucose Transport and Metabolism in Soleus Muscle}

The relationship between the dose-responses of inhibition of ${ }^{125} \mathrm{I}$-insulin binding and insulin-like effects of serum B-2 is shown in Figure 5 where the percent of maximal inhibition of binding and the percent of maximal stimulatory effects are plotted as a function of the serum concentration. The data indicate that maximally stimulated 2-deoxyglucose uptake, glycolysis, and glycogen synthesis occur with serum B-2 at 1:200 dilution, whereas maximal inhibition of ${ }^{125} \mathrm{I}$-insulin binding requires a $1: 30$ dilution. It can also be noted that the three curves of biological effects are superimposable, with half-maximal stimulation occurring at about 1:2000 dilution, whereas half-maximal inhibition of ${ }^{125} \mathrm{I}$-insulin binding requires a 1:500 dilution of the serum (Fig. 5).

\section{Effect of Serum B-2 on Glucose Metabolism in Soleus Muscle from Lean and Obese ob/ob Mice}

Soleus muscles of $o b / o b$ mice have been shown to have decreased ${ }^{125} \mathrm{I}$-insulin binding due to a decreased number of insulin receptor sites $[8,9]$. They are also characterized by a decreased insulin response of glucose metabolism, even when the hormone is used at maximally effective doses $[8,9]$. When muscles from $o b / o b$ mice were preincubated with serum B-2, the stimulation of glycolysis reached a level similar to that achieved with insulin, the effect being lower than that observed in lean muscles (Fig. 6). As previously described $[9,10]$, the response of glycogen synthesis to insulin was more

Table 2. Specificity of effect of serum B-2 on glucose metabolism in soleus muscle

\begin{tabular}{lllll}
\hline $\begin{array}{l}\text { Preincubation } \\
\text { conditions }\end{array}$ & Glycolysis & & \multicolumn{2}{l}{ Glycogen synthesis } \\
\cline { 2 - 5 } & Control serum & Serum B-2 & Control serum & Serum B-2 \\
\hline No addition & $23.7 \pm 2.0$ & $52.8 \pm 3.3$ & $1.6 \pm 0.3$ & $6.7 \pm 1.2$ \\
Anti IgG serum $1: 30$ & $27.4 \pm 1.3$ & $32.1 \pm 2.8$ & $1.6 \pm 0.3$ & $2.5 \pm 0.2$ \\
Anti-insulin serum 1:10000 & $24.7 \pm 1.3$ & $47.6 \pm 2.5$ & $1.5 \pm 0.1$ & $5.4 \pm 0.7$ \\
\hline
\end{tabular}

Muscles were preincubated with control serum or serum B-2 (1:500) as described in Figure 4. When indicated, anti-human IgG serum or anti-insulin serum was added during the preincubation period together with control serum or serum B-2. The results, expressed as nmoles of glucose converted into $\mathrm{H}_{2} \mathrm{O}$ (through the glycolytic pathway) or incorporated into glycogen per mg of protein, are means \pm SEM of 6 muscles 
markedly altered than the response of glycolysis in $o b / o b$ mice; furthermore, serum B-2 had a small effect on glycogen synthesis in muscles of $o b / o b$ mice (Fig. 6). Similar results were observed in experimentally induced goldthioglucose obese mice (data not shown).

\section{Discussion}

Circulating antibodies that block insulin binding to receptors in several tissues have been reported in diabetic patients with extreme insulin resistance, acanthosis nigricans, and autoimmune features $[1,2]$. In rat fat cells, the immunoglobulins that inhibit insulin binding also produce insulin-like effects $[6,7]$. In the present study, we have investigated the effects of one of these sera in the mouse soleus, a representative skeletal muscle. High dilutions $(1: 30$ to $1: 1000)$ of this serum significantly blocked insulin binding to its receptor in muscle (Figs. 1 and 2). This effect on insulin binding required relatively higher concentrations of serum in muscle than in isolated rat adipocytes [7] and human lymphocytes [5], presumably because of some diffusion barrier occurring in the whole muscle. However, the maximal inhibition of ${ }^{125} \mathrm{I}$-insulin binding obtained with a $1: 30$ dilution of serum B-2 was analogous to that produced by insulin at $200 \mathrm{ng} / \mathrm{ml}$, a concentration which is considered as nearly saturating the specific binding sites in the isolated soleus [9].

One of the most striking functional properties of some of these sera, in addition to their blocking effect on insulin binding, is their marked stimulatory, "insulin-like" effect on glucose metabolism. Thus, serum B-2 markedly stimulated 2-deoxyglucose uptake and glucose metabolism in soleus muscles (Figs. 3 and 4). Several lines of evidence strongly argue against the possible role of endogenous insulin and other serum factors in the observed effects: 1. The lack of effect of control serum on binding and biological parameters; 2 . The broad dilution range at which the patient's serum inhibited ${ }^{125}$ I-insulin binding and exerted insulin-like effects; 3 . The lack of significant inhibition of an anti-insulin serum on the serum's biological effects; 4 . The remarkable persistence of the serum effects after extensive washing of muscles and subsequent incubation in serum-free medium, even when an additional period of $3 \mathrm{~h}$ was introduced before the addition of substrate to measure biological effects (Table 1); 5. Lastly, the suppressive effect of an anti-human IgG serum on the serum's insulin-like effects. In addition, it has been shown that both the inhibitory and stimulatory effect of the antibody is retained in the $\mathrm{F}(\mathrm{ab})_{2}{ }_{2}$ component of the molecule [7]. These properties clearly indicate that antibody molecules are responsible for the stimulatory effects observed here on 2-deoxyglucose uptake and glucose metabolism in skeletal muscle.

The exact nature and precise mechanism(s), which underlie these effects, are still poorly understood. It is apparent that, in the mouse soleus, serum B-2 decreases insulin binding mainly by decreasing the affinity of the receptor for insulin (Fig. 2). A similar type of effect was observed in human cultured lymphocytes [5] and in rat adipocytes [7] with this serum. Serum B-2 was more potent in stimulating glucose transport and metabolism than in inhibiting insulin binding (Fig. 5). This is reminiscent of the relationship between insulin binding and insulin effects in soleus muscle, with non-superimposable dose-response curves [9], in keeping with the concept of spare receptors. Such a comparison between binding and action is, however, difficult to interpret for the patient's serum since its effect on binding is indirect (inhibition of ${ }^{125}$ I-insulin binding). Serum B-2 and insulin exerted effects which were partially additive only when both were used at submaximallystimulating concentrations (Table 3 ), suggesting that they are acting through a common pathway in stimulating 2-deoxyglucose uptake and glycolysis in skeletal muscle. Furthermore, the stimulatory effects of insulin and serum B-2 on glycolysis were reduced in a similar fashion in muscles from $o b / o b$ mice compared to lean mice (Fig. 6). Taken together, these results strongly suggest that some of the immunoglobulins present in the patient's serum interact with the insulin receptor or with some component of the receptor structure, and stimulate glucose transport and metabolism through a common pathway with insulin.

A striking feature of the present study is the observation that, whereas serum B-2 was as effective as insulin in maximally stimulating 2-deoxyglucose uptake and glycolysis, it was consistently less effective than the hormone in promoting glycogen synthesis (Figs. 5 and 6). It has been shown in muscle that the effect of insulin on glucose transport is entirely separable from the intracellular effect of the hormone on the activation of glycogen synthase [15]. Thus, both insulin and anti-insulin receptor antibodies may react with a common determinant of the insulin receptor structure to promote glucose transport and subsequent glycolysis through the same pathway. Insulin, but not the antibodies, would, in addition, be capable of stimulating intracellular specific processes such as the activation of glycogen synthase. The smaller (compared to insulin) stimulatory effect of the patient's serum on glycogen synthesis would then be the sole consequence of its 
effect on glucose transport. Whether this differential effect of insulin and patient's serum on glycogen synthesis arises from interaction with different components of the insulin receptor structure and/or from generation of different signals is unknown at present.

Immunoglobulin fractions which inhibit TSH binding to thyroid receptors and possess hormonelike effects have also been reported in patients with Graves' disease [16]. In the latter example, however, the stimulatory effects of antibodies occur also in vivo, in contrast to the observations made in the group of patients with insulin resistance, acanthosis nigricans and anti-insulin receptor antibodies whose insulin-like effects observed in vitro (as demonstrated in the present study) do not appear to be maintained in vivo. The mechanisms which may prevent such antibodies from acting in vivo are presently unknown. In patient B-2, the serum used for these studies was collected when the patient had severe insulin resistance and decreased receptor binding. In the latter course of the patient's disease, without any change in the titre of the anti-insulin receptor antibodies, the patient lost her requirements for insulin and in fact developed spontaneous hypoglycaemia [17]. The occurrence of hypoglycaemia in this patient could be explained by the unmasking in vivo of the insulin-like effects demonstrated here in vitro. Antibody heterogeneity appears to be a characteristic feature of these presumably autoimmune diseases. Variations in antibody populations, variations at the level of the hormone receptor, or both, may explain some of the apparent paradoxes between the effects of these immunoglobulins in vitro and in vivo.

Acknowledgements. We are indebted to Mrs. N. Grenier-Brossette for technical help, to Mr. G. Visciano for illustration work and to Miss J. Duch for excellent secretarial assistance.

This work was supported by grant A.T.P. 49.77 .81 of the Institut National de la Santé et de la Recherche Médicale (France).

\section{References}

1. Flier, J.S., Kahn, C. R., Roth, J., Bar, R. S.: Antibodies that impair insulin receptor binding in an unusual diabetic syndrome with severe insulin resistance. Science 190, 63-65 (1975)

2. Kahn, C. R., Flier, J.S., Bar, R.S., Archer, J. A., Gorden, P., Martin, M.M., Roth, J.: The syndromes of insulin resistance and acanthosis nigricans. Insulin-receptor disorders in man. $\mathrm{N}$. Engl. J. Med. 294, 739-745 (1976)
3. Flier, J.S., Kahn, C. R., Jarrett, D. B., Roth, J.: Characterization of antibodies to the insulin receptor. A cause of insulinresistant diabetes in man. J. Clin. Invest. 58, 1442-1449 (1976)

4. Jarrett, D. B., Roth, J., Kahn, C. R., Flier, J. S.: Direct method for detection and characterization of cell surface receptors for insulin by means of ${ }^{125} \mathrm{I}$-labeled autoantibodies against the insulin receptor. Proc. Natl Acad. Sci USA 73, 4115-4119 (1976)

5. Flier, J.S., Kahn, C.R., Jarrett, D.B., Roth, J.: Autoantibodies to the insulin receptor. Effect on the insulin-receptor interaction in IM-9 lymphocytes. J. Clin. Invest. 60, 784-794 (1977)

6. Kahn, C. R., Baird, K., Flier, J. S., Jarrett, D. B.: Effect of antiinsulin receptor antibodies on isolated adipocytes. Diabetes 25, 322 (1976) (Abstract)

7. Kahn, C. R., Baird, K., Flier, J.S., Jarrett, D. B.: Effects of autoantibodies to the insulin receptor on isolated adipocytes. Studies of insulin binding and insulin action. J. Clin. Invest. 60, 1094-1106 (1977)

8. Le Marchand, Y., Jeanrenaud, B., Freychet, P.: Insulin binding and insulin effect in the isolated mouse soleus muscle. Diabetes 26 (Suppl. 1), 355 (1977) (Abstract)

9. Le Marchand-Brustel, Y., Jeanrenaud, B., Freychet, P.: Insulin binding and effects in the isolated soleus muscle of lean and obese mice. Am. J. Physiol. (In press) (1978)

10. Cuendet, G. S., Loten, E. G., Jeanrenaud, B., Renold, A. E.: Decreased basal, non-insulin stimulated glucose uptake and metabolism by skeletal soleus muscle isolated from obesehyperglycemic $(o b / o b)$ mice. J. Clin. Invest. 58, 1078-1088 (1976)

11. Dawson, R.M.C., Elliott, D. C., Elliott, W. H., Jones, K. M (eds.): Data for biochemical research, 2nd edition, p. 507. Oxford: Clarendon Press 1969

12. Lowry, O.H., Rosebrough, N.J., Farr, A.L., Randall, R. J.: Protein measurement with the Folin phenol reagent. J. Biol. Chem. 193, 265-275 (1951)

13. Ashcroft, S.J.H., Weerasinghe, L.C.C., Bassett, J.M., Randle, P.J.: The pentose cycle and insulin release in mouse pancreatic islets. Biochem. J. 126, 525-532 (1972)

14. Snedecor, G. W., Cochran, W. G.: Statistical methods, 6th edition. Ames: Iowa State University Press 1967

15. Larner, J., Villar-Palasi, C.: Glycogen synthase and its control. Curr. Top. Cell. Regul. 3, 195-236 (1971)

16. Smith, B. R., Hall, R.: Thyroid stimulating immunoglobulins in Graves' disease. Lancet 1974 II, 427-430

17. Bar, R.S., Flier, J.S., Jarrett, D.B., Gorden, P.: Hypoglycemia and proliferation of low affinity insulin receptors in a patient with anti-receptor antibodies. Diabetes 26 (Suppl. 1), 354 (1977)

Received: September 21, 1977,

and in revised form: December 8, 1977

Y. Le Marchand-Brustel

I.N.S.E.R.M., U 145

Faculté de Médecine (Pasteur)

Chemin de Vallombrose

F-06034 Nice Cedex

France 